\title{
Physical and chemical characteristics of soil from tiger shrimp aquaculture ponds at Malacca, Malaysia
}

\begin{abstract}
Soil physicochemical properties of the growout ponds of black tiger shrimp (Penaeus monodon) were examined in relation to shrimp yields for one production cycle. The culture ponds were old (>5 years) and new (newly constructed) types. Soil texture was silty clay with low sand content and high proportion of clay for both the pond types with alkaline soil $\mathrm{pH}$ (7.87-9.71). Organic matter $(\mathrm{OM})$ concentration was higher $(7.48 \pm 0.01 \%)$ in old ponds and positively related $(\mathrm{r}=0.58, \mathrm{P}<0.05)$ with total nitrogen $(\mathrm{TN})$. The major cations $(\mathrm{Ca}, \mathrm{Mg}$, and $\mathrm{Na}$ ) were higher in the soil of old ponds and did not fluctuate significantly during culture. The majority of trace elements, i.e., Fe $(349.22 \pm 35.7 \mathrm{ppm})$, Mn $(56.19 \pm 30.2 \mathrm{ppm}), \mathrm{Zn}(88.56 \pm$ $8.09 \mathrm{ppm}), \mathrm{Al}(454.3 \pm 200.6), \mathrm{Pb}(1.3 \pm 0.96 \mathrm{ppm}), \mathrm{Co}(3.4 \pm 0.2), \mathrm{V}(6.56 \pm 1.79 \mathrm{ppm}), \mathrm{Cr}$ $(19.32 \pm 0.63 \mathrm{ppm}), \mathrm{Ti}(82.78 \pm 54.3 \mathrm{ppm})$, As $(5.60 \pm 0.28 \mathrm{ppm}), \mathrm{Ag}(0.38 \pm 0.5 \mathrm{ppm})$, and $\mathrm{Sb}(3.89 \pm 0.48 \mathrm{ppm})$ were found to be higher in new pond soils than the old ponds. Except for soil manganese, no major fluctuations in trace elements were observed during the culture period. Shrimp growth was not significantly different in the two types of ponds, and no distinct correlation between shrimp growth and element content of soils could be drawn. The results indicate that shrimp pond age may not affect production of shrimp if soils are properly managed pre- and postculture. The differences in production in different ponds might be the result of management practice such as quality of shrimp post larvae, pond preparation, water and feed quality, and available live feed in the pond bottom or other environmental factors like water nutrients and physicochemical parameters.
\end{abstract}

Keyword: Aquaculture; Compositions; Soils; P. monodon; Malaysia 